\title{
Correction to: TRIM29 facilitates the epithelial-tomesenchymal transition and the progression of colorectal cancer via the activation of the $\mathrm{Wnt} / \beta$-catenin signaling pathway
}

Juntao Sun ${ }^{\dagger}$, Tianyu Zhang ${ }^{\dagger}$, Mengmeng Cheng, Liwen Hong, Chen Zhang, Mengfan Xie, Peijun Sun, Rong Fan, Zhengting Wang, Lei Wang ${ }^{*}$ and Jie Zhong ${ }^{*}$

Correction to: J Exp Clin Cancer Res 38, 104 (2019) https://doi.org/10.1186/s13046-019-1098-y

Following the publication of the original article [1], the authors identified minor errors in image-typesetting in Fig. 2, Fig. 6 and Fig. 7; specifically panels Fig. 2h, Fig. 6d and Fig. 7c. The specific panels that have been corrected are as follows:

- Fig. $2 \mathrm{~h}$ : all migration and invasion panels

- Fig. 6d: all panels

- Fig. 7c: both XAV939(+) panels

The corrected figures are provided below. The corrections do not have any effect on the results or conclusions of the paper. The original article has been corrected.

Published online: 28 April 2021

\section{Reference}

1. Sun J, Zhang T, Cheng M, et al. TRIM29 facilitates the epithelial-to-

mesenchymal transition and the progression of colorectal cancer via the activation of the Wnt/ $\beta$-catenin signaling pathway. J Exp Clin Cancer Res. 2019;38:104 https://doi.org/10.1186/s13046-019-1098-y.

The original article can be found online at https://doi.org/10.1186/s13046019-1098-y.

* Correspondence: raylwang@hotmail.com; Jimmyzj64@hotmail.com

${ }^{\dagger} J u n t a o$ Sun and Tianyu Zhang contributed equally to this work.

Department of Gastroenterology, Ruijin Hospital, Shanghai Jiao Tong

University School of Medicine, Shanghai 200025, China

(c) The Author(s). 2021 Open Access This article is licensed under a Creative Commons Attribution 4.0 International License, which permits use, sharing, adaptation, distribution and reproduction in any medium or format, as long as you give appropriate credit to the original author(s) and the source, provide a link to the Creative Commons licence, and indicate if changes were made. The images or other third party material in this article are included in the article's Creative Commons licence, unless indicated otherwise in a credit line to the material. If material is not included in the article's Creative Commons licence and your intended use is not permitted by statutory regulation or exceeds the permitted use, you will need to obtain permission directly from the copyright holder. To view a copy of this licence, visit http://creativecommons.org/licenses/by/4.0/ The Creative Commons Public Domain Dedication waiver (http://creativecommons.org/publicdomain/zero/1.0/) applies to the data made available in this article, unless otherwise stated in a credit line to the data. 


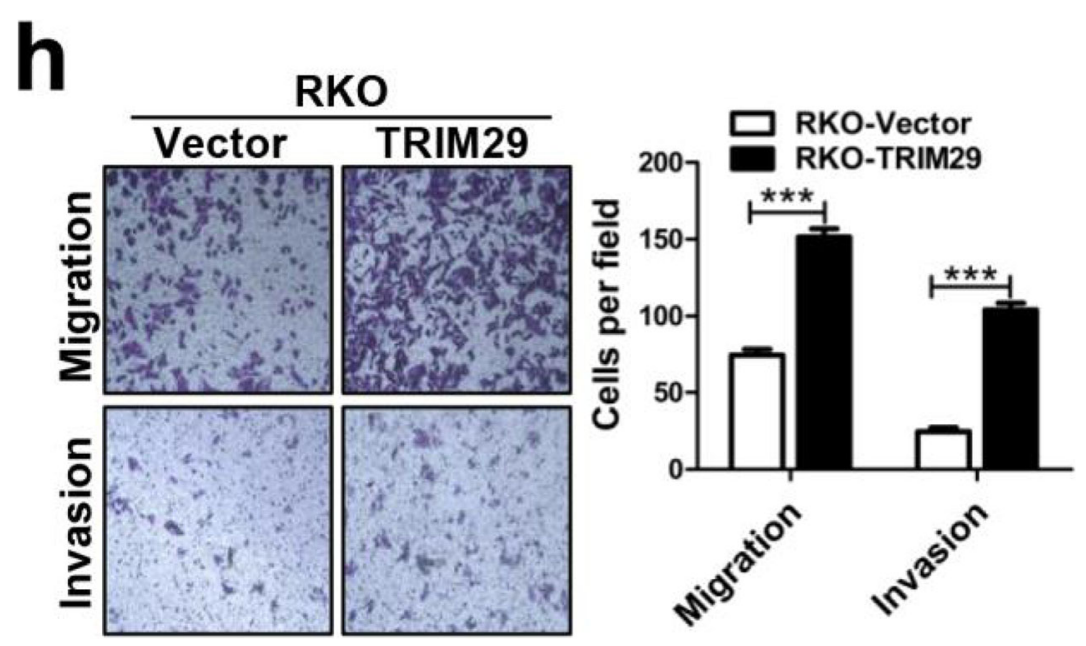

Fig. $\mathbf{2} \mathbf{h}$ The migration and invasion assays showed different cell motilities in modified RKO cells. Overexpression of TRIM29 promoted the migration and invasion of RKO cells. All of the data are presented as the mean \pm SEM. from three independent experiments $\left({ }^{* * *} P<0.001\right)$

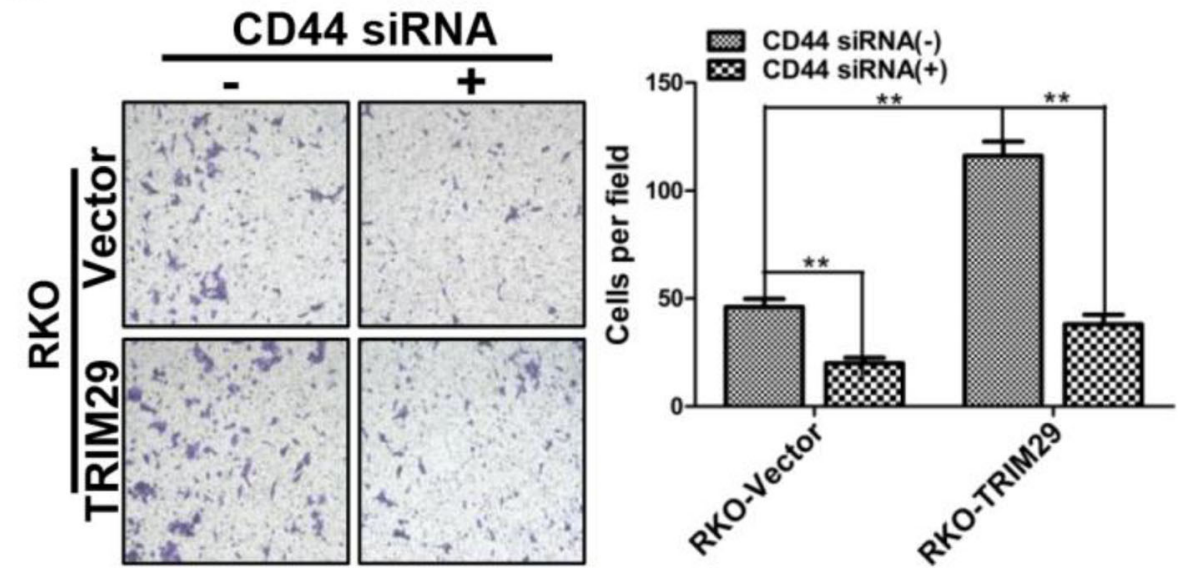

Fig. $6 \mathbf{d}$ The Transwell invasion assay showed different cell invasive abilities in RKO-Vector and RKO-TRIM29 cells which were transfected with negative control siRNA or siRNA against all CD44 isoforms. The data are presented as the mean \pm SEM from three independent experiments $\left({ }^{*} P<0.01\right)$ 

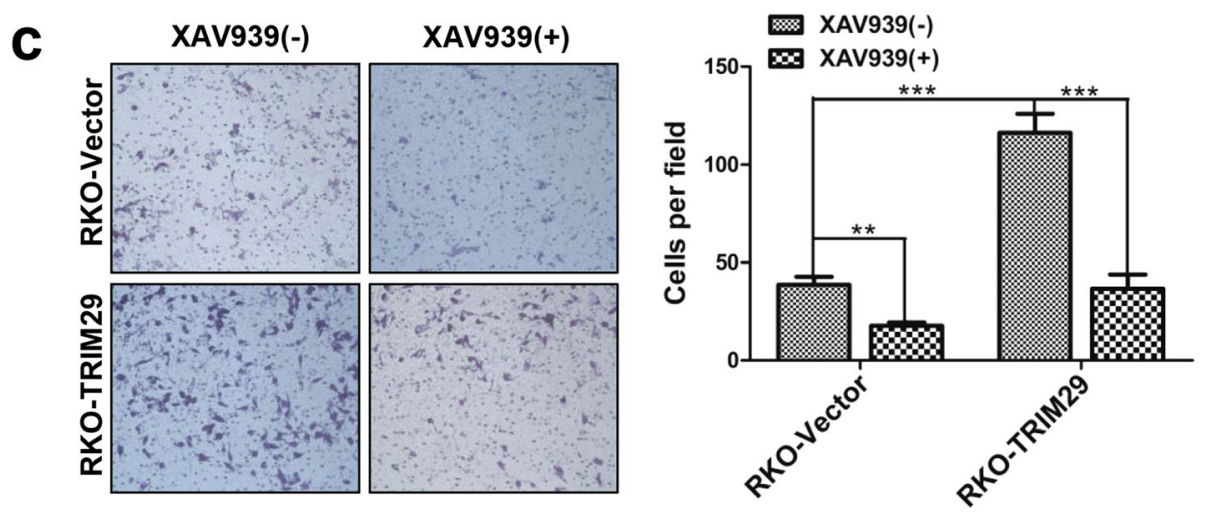

Fig. 7 c The Transwell invasion assay showed different cell invasive abilities in RKO-Vector and RKO-TRIM29 cells with XAV939 (15 $\mu \mathrm{M})$ for $24 \mathrm{~h}$. The data are presented as the mean \pm SEM. from three independent experiments ${ }^{* *} P<0.01$, ${ }^{* *} P<0.001$ ) 